
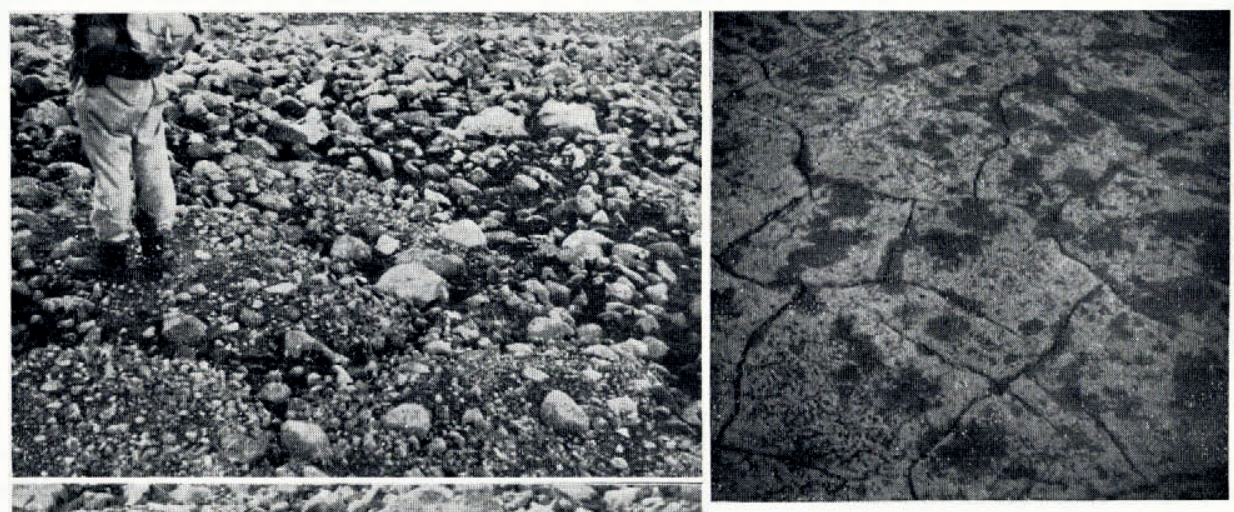

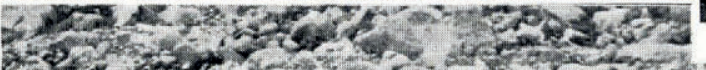
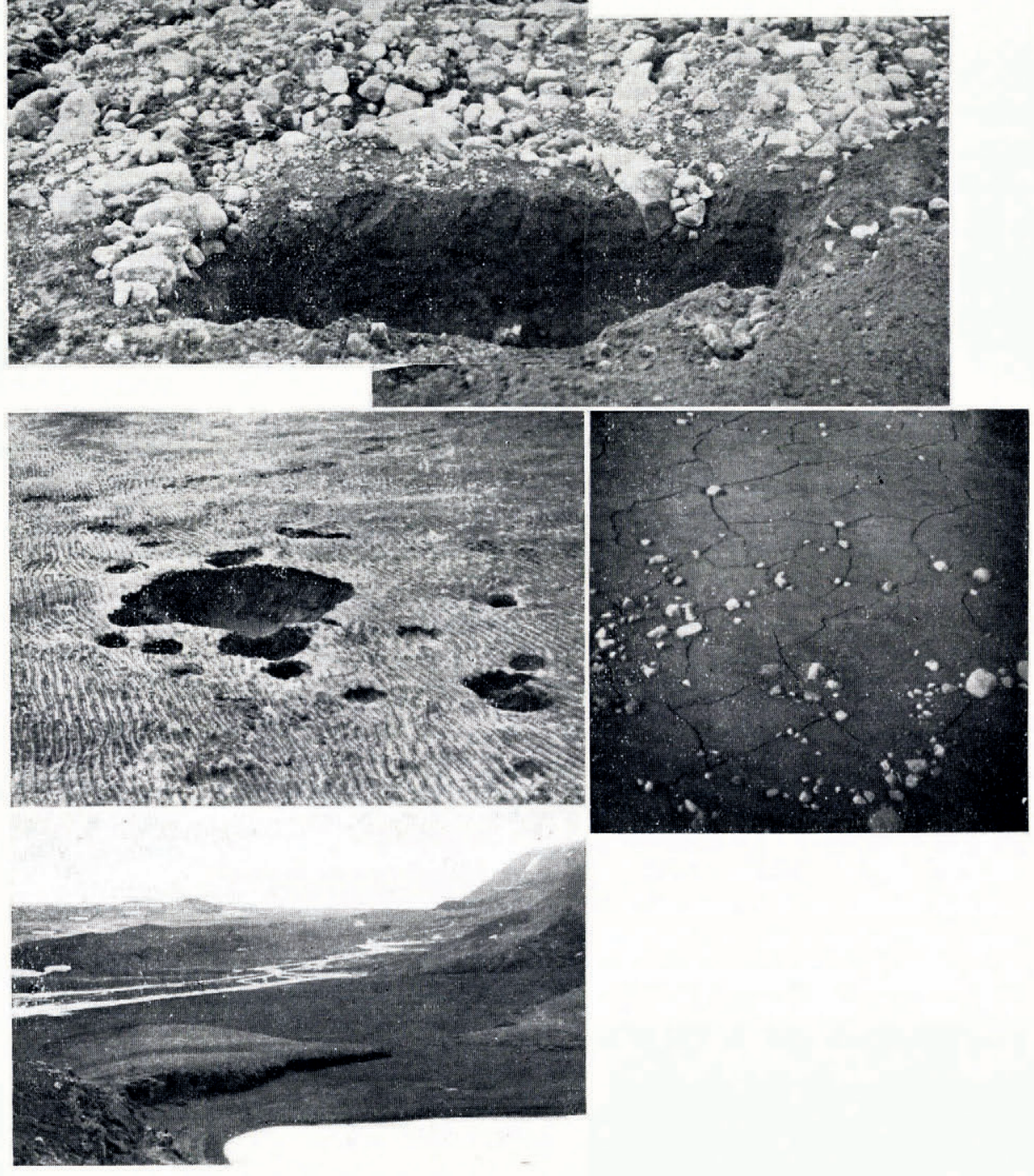


\title{
AN INVESTIGATION OF SOME SOIL POLYGONS IN CENTRAL ICELAND
}

\author{
By M. W. Dyвeck \\ (Brathay Hall Centre)
}

\begin{abstract}
Near the edge of Langjökull ice cap there are many soil polygons. A cross-section showed them to be only surface features consisting of rocks in polygonal form embedded in silt. The area revealed much evidence that silt and small rocks often behaved like a liquid upon which heavier rocks would float. If the floating heavier rocks were pushed down into the "liquid," mud would, in certain circumstances, ooze up a metre or so away. If a number of rocks were depressed the mud would ooze at points roughly equidistant from a few of the rocks, and spread to leave a polygon pattern. Conditions favourable for the sinking of heavy stones in this manner probably occur each spring.

Zusammenfassung. Nahe dem Rande der Langjökull-Eiskappe gibt es viele Erd-Polygone. Von einem Querschnitt war zu ersehen, dass es sich nur um Oberflächenformationen, die aus in Triebsand eingebetteten polygonalförmigen Felsstücken bestehen, handelt. Das Gebiet ergab vielerlei Beweise, dass Triebsand und kleine Felsstücke sich oft wie eine Flüssigkeit benahmen, auf der schwere Felsstücke treiben konnten. Wenn die treibenden, schwereren Felsstücke in die „Flüssigkeit" hineingestossen wurden, so quellte unter bestimmten Umständen in ungefähr ein Meter Entfernung. Schlamm herauf. Wenn eine Anzahl Felsstücke hinuntergedrückt wurden, so quellte der Schlamm an Punkten in ungefähr gleicher Entfernung von einigen dieser Felsstücke herauf, breitete sich aus und hinterliess ein polygonales Muster. Möglicherweise bestehen jeden Frühling solche Bedingungen, die das Einsinken schwerer Steine auf diese Weise begünstigen.
\end{abstract}

A NUMBER of soil polygons of widely differing shapes and sizes and in what appeared to be various stages of development were studied at the edge of the Langjökull Ice Cap about $80 \mathrm{~km}$. north-east of Reykjavik. The area included the eastern end of Langjökull and extended east across the northsouth pass which is free of ice and on to the small round volcanic hill called Ok, which now has only a small remnant of an ice cap.

The surface material was composed largely of pre-glacial or inter-glacial lava flows modified by faults and ice action; this had presumably been gradually exposed by the retreating ice caps during recent time. This presumption was supported by the fact that the best-developed polygons were well away from the ice caps; near the ice caps no clearly defined polygons were found.

$\mathrm{On}$ the eastern side of $\mathrm{Ok}$ and about half-way between the summit and the valley at about $800 \mathrm{~m}$., we came across some very pronounced polygons. These were on slightly sloping ground and usually measured about one to two metres across (Fig. I, p. I42). In places they covered several acres without any break in pattern, but elsewhere patches of unsorted rocks occurred. There seemed to be no relation between slope of ground and occurrence of polygons.

We were interested to find out how far beneath the surface these patterns would be recognized, and what modifications occurred with the increasing depth. We therefore selected a particularly clear polygon area and dug a trench right across the centre of a polygon cutting through and extending lengthwise beyond its circumference. This trench was about $2 \frac{1}{2} \mathrm{~m}$. long and about $80 \mathrm{~cm}$. deep (Fig. 2, p. I $4^{2}$ ). The photograph shows clearly that the stone pattern which formed the perimeter of the polygon does not persist below about $30 \mathrm{~cm}$. A close examination of the fine silty ground below this depth showed that there was no difference between that under the perimeter and that under the centre of the polygon.

Fig. I (top left). The slope of the ground seemed unrelated to the occurrence of these polygons. In this area there were polygons on ground varying from level to about 5 degrees. Here the slope is about 2 degrees

Fig. 2 (second row). Rocks, though predominating at the surface, were very few underground. This polygon is about $2 \frac{1}{2} \mathrm{~m}$. in width and rocks extend to about $30 \mathrm{~cm}$. below the surface

Fig. 3 (bottom). An area of soft glacial mud and debris south-west of Langjökull

Fig. 4 (third row left). "Craters" left by stones sinking in glacial mud, photographed immediately after sinking. Distance across big hole approx. $20 \mathrm{~cm}$.

Fig. 7 (top right). Polygonal cracks suitable for trapping small rocks

Fig. 8 (third row right). Rocks which are in or near cracks may well have been trapped there when rolling across the area during a flood 
The extent to which rocks float in mud has probably been insufficiently emphasized in most solifluction studies. In the Thórisdalur area just south of the western end of Langjökull, the ice cap has retreated about $100 \mathrm{~m}$. in the last 19 years* and the newly exposed area is largely a great conglomeration of boulders of all sizes, gravel, ice, mud, and water. When the ice melts out of this chaos the resulting water seems to be absorbed by the fine gravel to form a very wet mud (Fig. 3 , p. 142). This mud seems to act like a very dense liquid with a crust upon it. A walker can easily make any open expanse of it ripple like water, and any heavy object on it which breaks the crust steadily sinks below the surface. (A human being usually had to keep moving to avoid sinking.) A most striking instance of this breaking of the crust occurred as we were rapidly crossing a large mud flat. Our passage must have caused quite an extensive upset of the crust for, five metres away, a number of stones of about 4 to $20 \mathrm{~cm}$. diameter gently subsided into the mud (Fig. 4, p. I42). Smaller stones nearby were unaffected by our passage.

In order to investigate further any relationship between buoyancy and polygonal sorting it was necessary to find some area where there was (a) much mud, (b) plenty of undifferentiated stones. Close to the summit of $\mathrm{Ok}$ we found such a place.

Recent recession of the ice on $\mathrm{Ok}$ has led to the exposure of the summit which is a volcanic crater about $\frac{3}{4} \mathrm{~km}$. in diameter and some $100 \mathrm{~m}$. deep. As yet only the perimeter of the crater and the subsidiary crater in the middle are free of ice and these parts protrude as nunataks. It was in this subsidiary crater that the conditions for possible polygon formation were observed. Part of the area sloped at only about one degree to the south. Some rudimentary polygons were observed, but much of the ground was still a chaos of muddy moraine. Rocks varied in size from about $30 \mathrm{~cm}$. in diameter to fine glacial sand. Almost all were very angular.

Walking across this area was very similar to walking across the Thórisdalur mud flats. Despite the heavy cover of rocks the ground behaved like a liquid and rippled as one jumped on it. It was, however, a more dense liquid than that at Thórisdalur since none of the stones sank as a result of disturbing the surface. In fact, this mud behaved more like a jelly. However, the mud was not firm enough to support the weight of a big stone plus the weight of a man standing on it. The effect of one such overloaded stone sinking did not have any noticeable effect on the rest of the area. Presumably the displaced mud spread out and raised the nearby ground a fraction but that is all. If, on the other hand, one were to postulate a large number of overloaded stones, then their displacing effects, on sinking, might be more significant. Much mud would be displaced and would presumably flow underground away from these boulders. It could not ooze up beside the boulders because the slight crust would normally not be broken except where the boulders had sunk in (Fig. 5, p. 145).

We tried to test this idea by standing on two of the larger boulders, which were about one metre apart, and caused them to sink. As they sank, the area rose a little and soon thick mud was welling out from the area roughly equidistant between the stones. Many smaller rocks were moved by the flow of this mud. The heavy stones now made an area lower than the rest of the surroundings and so the mud tended to flow back along the surface towards these stones. Soon, from this formerly undifferentiated rubble, we had produced artificially what looked very like a soil polygon.

Now what we were able to do with two heavy stones might have been done far more effectively if we had, say, twenty heavy stones. No matter how indiscriminate their arrangement, it would frequently be an easy matter to imagine "centres of oozing" distributed among them which, when functioning, would well out mud and this would spread to the heavy stones leaving a polygon pattern (Fig. 6, p. I45).

It only remains to imagine some natural cause which would sink the heavy stones which, in our case, were sunk by the weight of man. Now we have seen by the comparison with the Thóris-

* For details of this recession see: Wright, J. W. The Hagavatn Gorge. Geographical Fournal, Vol. 86, 1935, p. $218-$ 34. See also $x: 1,000,000$ maps from aerial photographs by the Danish Geodetic Institute, 1938, and a note by the author on p. 127-29 of the Geographical fournal, Vol. 123, No. 1, March 1957. 
dalur mud that the buoyancy of mud is very variable. At times it may be so watery that it can support only the smallest stones. At other times it may be so stiff that only a heavy man will sink. On other occasions, probably every year during the Spring melting, it may be jelly-like and then only the lighter stones would be supported. As the winter freeze ends, the heavy stones may sink, promoting oozing up between the stones, carrying the lesser stones away from the oozing and leaving a mud-centred polygon.

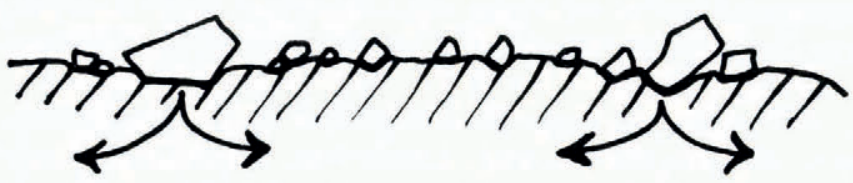

Fig. 5 .

Stage I: Mud still in winter freeze. Arrows show direction in which the mud will tend to flow

Stage II: Mud cannot now support rocks $\mathrm{A}$ and $\mathrm{B}$. Mud flows away from $\mathrm{A}$ and $\mathrm{B}$ and oozes out of $\mathrm{C}$

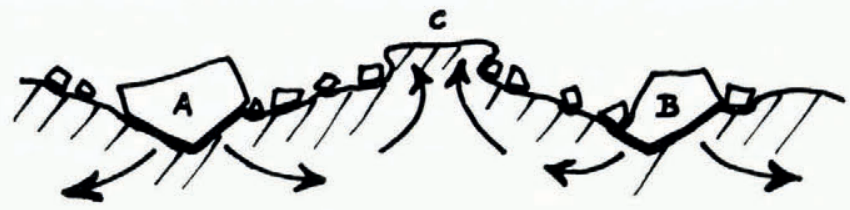

Small stones are carried towards $\mathrm{A}$ and $\mathrm{B}$ by gravity and by the moving mud

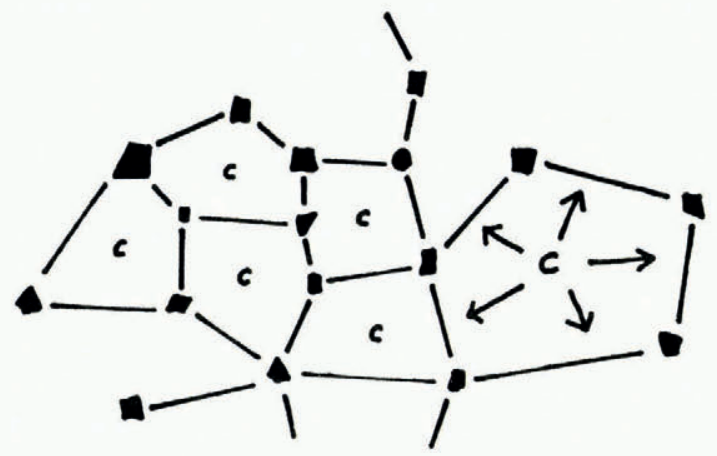

Fig. 6. Indiscriminately distributed heavy stones can easily form the basis of a polygon system. $\mathrm{C}$ denotes centres of oozing

Another possible method of polygon formation in certain dried-up lakes may be worth noting. One or two such lakes exist in the valley to the east of Ok. The mud in them had cracked on drying to form polygons of $\frac{1}{2}$ to 2 metres in diameter (Fig. 7, p. 142). Presumably at certain times of the year these lakes are filled with water. It is possible that sometimes this filling may begin with a sudden onrush of water which would bring with it some of the stones from nearby. Such stones would move by sliding and rolling and many of them would be trapped in the cracks (Fig. 8). Those that fell down the cracks would later emerge at the surface as the finer particles were blown away when the terrain had become dry again. A line of stones, when trapped, would provide a barrier for other and larger stones, and in time sufficient stones could rest along the lines of the old mud cracks to make quite a pronounced polygon pattern. While this action can only have a very limited application, it may nevertheless explain some of the polygons in flat areas.

\section{ACKNOWLEDGEMENT}

I wish to express my thanks to Mr. W. V. Lewis for reading through and commenting on this paper.

MS. received 30 October 1956 